\title{
Peningkatan Kualitas Generasi Sadar Kesehatan Reproduksi Remaja Putri Sma Muhammadiyah I Bantul
}

\author{
Nur Hayati', Alfaina Wahyuni², dan Alfun Dhiya An² \\ 1. Radiologi FKIK UMY, Yogyakarta, Indonesia \\ 2 Ilmu Kebidanan dan Kandungan FKIK UMY, Yogyakarta, Indonesia \\ Fakultas Kedokteran dan Ilmu Kesehatan UMY, Jl. Brawijaya, Bantul, D.I.Yogyakarta, 55183, telp 0274387656 \\ Email: nurhayati.fk.umy@gmail.com \\ DOI: $10.18196 / \mathrm{ppm} .36 .312$
}

\begin{abstract}
Abstrak
Kesehatan reproduksi sangat penting untuk dipahami oleh semua orang, khususnya remaja putri. Banyak remaja mendapatkan pengetahuan mengenai kesehatan reproduksi dari media sosial yang tidak terjamin kebenarannya. Kegiatan pengabdian masyarakat ini bertujuan untuk meningkatkan kualitas kesadaran remaja mengenai kesehatan reproduksi. Mitra kegiatan ini adalah remaja putri siswi SMA yang rentan terhadap pengaruh negatif dari media sosial maupun lingkungannya. Metode pengabdian masyarakat dengan mengadakan webinar yang diikuti oleh siswa SMA. Pembicara menyampaikan materi mengenai kesehatan reproduksi melalui webinar dan membuat poster-poster untuk dibaca oleh mitra. Sebelum mengikuti webinar siswa diuji pengetahuannya mengenai kesehatan reproduksi dengan pretest. Setelah mendapatkan pemaparan materi, dilakukan postest. Hasil analisis pretest dan postest menunjukkan peningkatan pengetahuan siswa mengenai kesehatan reproduksi. Pengabdian masyarakat dengan webinar dan pembuatan poster dapat meningkatkan pengetahuan siswa mengenai kesehatan reproduksi.
\end{abstract}

Kata kunci: Remaja putri, kesehatan reproduksi, webinar

\section{Pendahuluan}

Kesehatan reproduksi menurut peraturan pemerintah Republik Indonesia nomor 61 tahun 2014 adalah keadaan sehat secara fisik, mental, dan soisal secara utuh, tidak semata-mata bebas dari penyakit atau kecacatan yang berkaitan dengan sistem, fungsi, dan proses reproduksi. Tersirat dalam kesehatan reproduksi adalah hak pria dan wanita untuk mendapatkan dan memiliki akses ke informasi metode keluarga berencana yang aman, efektif, mampu, dan dapat diterima, serta juga metode lainnya untuk pengaturan kesuburan yang tidak bertentangan dengan hukum, dan hak akses ke layanan perawatan kesehatan yang sesuai dan memungkinkan wanita dapat dengan aman menjalani kehamilan dan persalinan dan memberi pasangan kesempatan terbaik untuk memiliki bayi yang sehat (Kusmiran, 2012 dan PP RI, 2014).

Remaja menurut WHO didefinisikan sebagai penduduk dalam rentang usia 10-19 tahun, menurut Peraturan Menteri Kesehatan RI Nomor 25 tahun 2014, remaja adalah penduduk dalam rentang usia 10-18 tahun dan menurut Badan Kependudukan dan Keluarga Berencana (BKKBN) rentang usia remaja adalah 10-24 tahun dan belum menikah. Masa remaja adalah masa peralihan atau masa transisi dari anak menuju masa dewasa yang ditandai oleh adanya perubahan fisik, emosi, dan psikis. Pada masa ini begitu pesat mengalami pertumbuhan dan perkembangan baik itu fisik maupun mental. Fase remaja ini juga merupakan waktu terjadinya pematangan organ reproduksi manusia sehingga sering disebut masa peralihan. Pada rentang usia tersebut, umumnya remaja ini sedang menempuh pendidikan formal mereka di SMP, SMA dan kuliah di perguruan tinggi (Johariyati dan Mariyah, 2018). 
Pada saat ini akses informasi bagi remaja Indonesia mengenai kesehatan reproduksi masih sangat terbatas karena masih banyaknya masyarakat yang beranggapan bahwa seksualitas adalah hal yang tabu untuk dibicarakan. Keterbatasan akses informasi mengenai kesehatan reproduksi mengakibatkan kurangnya tingkat pengetahuan, sifat dan perilaku berisiko pada remaja yang berdampak pada status kesehatan reproduksi remaja. Keadaan ini memerlukan ketersediaan pelayanan kesehatan peduli remaja yang dapat memenuhi kebutuhan kesehatan remaja khususnya pelayanan untuk kesehatan reproduksi yang ramah dengan remaja (Johariyati dan Mariyah, 2018).

Berdasarkan permasalahan yang telah dijelaskan, pengusul berupaya meningkatkan pengetahuan dan melatih keterampilan siswi SMA Muhammadiyah 1 Bantul mengenai kesehatan reproduksi. Tujuan dilaksanakannya kegiatan ini adalah untuk meningkatkan kualitas generasi sadar kesehatan reproduksi. Meningkatnya pengetahuan dan keterampilan mereka, diharapkan siswi SMA Muhammadiyah 1 Bantul dapat secara aktif dan mandiri dalam menjaga kesehatan reproduksinya dan menjadi generasi yang sadar kesehatan reproduksi.

Metode Pelaksanaan

Kegiatan penyuluhan kesehatan ini adalah program berbasis masyarakat, sehingga kegiatan ini menggunakan pendekatan partisipatif.

Tahap-tahap pelaksanaannya sebagai berikut:

1. Koordinasi dengan calon mitra untuk merancang kegiatan

Pengusul berkomunikasi dan koordinasi dengan pihak SMA Muhammadiyah 1 Bantul untuk menentukan metode yang sesuai dengan kebutuhan mitra dalam masa pandemi covid-19 ini.

2. Penyusunan proposal

Setelah mendapatkan metode yang sesuai, pengusul menulis proposal dengan memperhatikan analisis situasi, tinjauan literatur terbaru dan tujuan dilaksanakannya pengabdian masyarakat.

3. Penggalangan dukungan ke pihak terkait

Pengusul mengajukan proposal ke pihak pemberi dana untuk mendapatkan dukungan pembiayaan kegiatan dan narasumber untuk memberikan materi penyuluhan kepada mitra.

4. Penyusunan rencana kegiatan

Pengusul bersama narasumber dan mitra menyusun rencana kegiatan sesuai analisis situasi dan pendanaan.

5. Penyiapan infrastruktur

Penyuluhan dilaksanakan secara online/webinar. Pengusul menyiapkan zoom berbayar dan kuota data kepada mitra supaya bisa mengikuti kegiatan webinar.

6. Pelaksanaan kegiatan secara bertahap

Kegiatan dimulai dengan penyuluhan kesehatan reproduksi. Setelah itu pengusul menyerahkan poster-poster mengenai kesehatan reproduksi dan poster pencegahan penularan covid serta wastafel untuk cuci tangan.

7. Monitor dan evaluasi

Monitoring dilakukan dengan cara berkomunikasi aktif dengan mitra mengenai implementasi pengetahuan yang sudah didapatkan.

8. Pengembangan kegiatan

Dilakukan MOU oleh institusi pengusul dan mitra untuk pelaksanaan kegiatan-kegiatan berbasis kesehatan di institusi mitra oleh institusi pengusul. 
Hasil dan Pembahasan

Kegiatan pengabdian masyarakat yang berupa webinar dan pemasangan poster telah dilaksanakan pada tanggal 10 September 2020 dan 13 September 2020. Kegiatan webinar berupa pemaparan materi kesehatan reproduksi oleh dokter ahli kebidanan dan kandungan (Gambar 1). Webinar dihadiri oleh dihadiri siswi sebagai sasaran pengabdian masyarakat, guru, kepala sekolah dan karyawan yang akan menjadi pendamping pembentukan generasi sadar kesehatan reproduksi. Peserta diminta mengisi pretest dan postest sebelum dan sesudah mengikuti ceramah untuk mengetahui tingkat pengetahuan mereka mengenai kesehatan reproduksi.

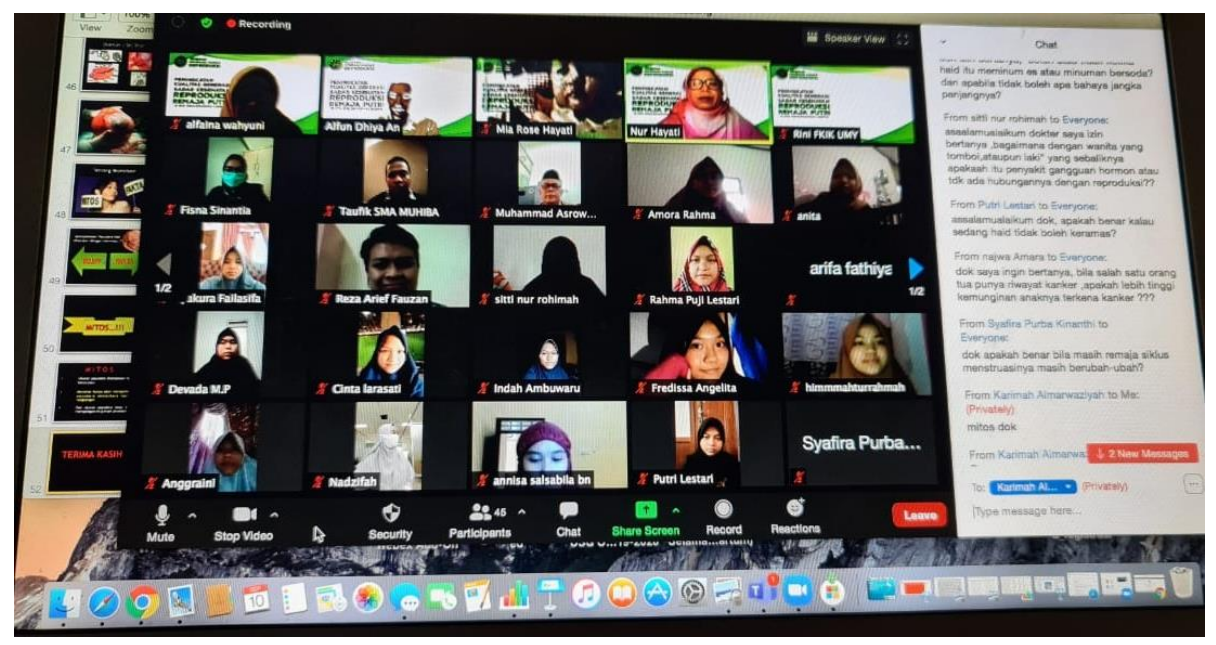

\section{Gambar 1. Foto tangkapan layar pelaksanaan webinar pemaparan materi kesehatan reproduksi}

Hasil kegiatan pengabdian masyarakat ini menunjukkan bahwa sebelum mengikuti ceramah, sebagian besar siswi SMA Muhammadiyah 1 Bantul belum memiliki pengetahuan yang baik dan benar mengenai kesehatan reproduksi. Masih banyak siswi SMA Muhammadiyah 1 Bantul yang masih merasa bingung dan malu dalam membicarakan masalah kesehatan reproduksi. Hal ini disebabkan karena mereka merasakan bahwa topik yang kesehatan reproduksi ini adalah hal yang tabu dan takut untuk membicarakannya. Sebagian besar subjek lebih banyak menggunakan internet, bertanya pada teman maupun menggunakan sosial media untuk mendapatkan informasi mengenai seputar kesehatan reproduksi. Keadaan ini sesuai dengan hasil penelitian Nasution (2012) mengenai pengetahuan remaja tentang kesehatan reproduksi dan cara-cara melindungi diri dari berbagai resiko atau masalah kesehatan reproduksi yang masih sangat rendah dan perlu mendapatkan perhatian dari pihak-pihak terkait. Pengetahuan dan pemahaman remaja putri mengenai seputar kesehatan reproduksi yang masih rendah mengakibatkan remaja putri rentan mengalami permasalahan kesehatan reproduksi. Oleh karena itu pemberian informasi yang benar dari pihak-pihak terkait, khususnya orang tua sangat diperlukan untuk meningkatkan pengetahuan mereka. Orang tua merupakan sumber informasi terbaik bagi remaja putri dalam hal kesehatan reproduksi dan peran orang tua memiliki pengaruh kuat terhadap pengetahuan mereka. (Ernawati, 2018). 
Pemaparan materi kesehatan reproduksi oleh narasumber dilakukan secara interaktif dan menggunakan media audiovisual berupa slide presentasi dengan gambar dan tampilan yang menarik. Melalui metode ini para peserta lebih tertarik dan minat untuk mengikuti jalannya webinar dapat meningkat dan tujuan webinar dapat dicapai. Keadaan ini sesuai dengan hasil penelitian yang dilakukan oleh Johariyah \& Mariati (2018) yang menunjukkan bahwa media ajar yang menarik dalam penyuluhan kesehatan mampu mempengaruhi perubahan pengetahuan remaja. Kuis-kuis yang disampaikan oleh pemateri selama pemaparan dapat direspon oleh peserta dengan cepat dan benar. Demikian juga sebaliknya, para peserta juga aktif mengajukan pertanyaan-pertanyaan seputar kesehatan reproduksi. Keaktifan peserta dalam menjawab kuis dari pemateri dapat dilihat pada Gambar 2.

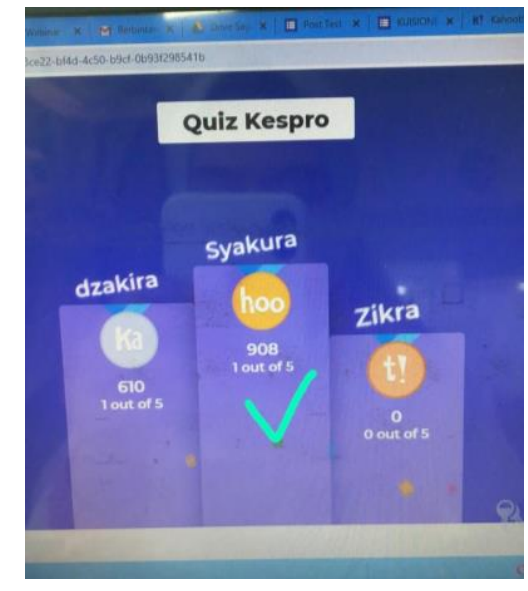

\section{Gambar 2. Tampilan layar keaktifan peserta menjawab kuis}

Setelah mengikuti webinar, para peserta diminta mengerjakan postest untuk mengukur peningkatan pengetahuan mereka mengenai kesehatan reproduksi. Berdasarkan hasil postest, dapat dilihat bahwa siswi SMA Muhammadiyah 1 Bantul mengalami peningkatan pengetahuan kesehatan reproduksi yang signifikan $(\mathrm{p}<0,05)$. Hal ini sejalan dengan hasil pengabdian masyarakat yang dilaksanakan oleh Yarsa dkk (2019), yakni target pengabdian masyarakat menjadi lebih baik pengetahuannya dan memiliki sikap yang lebih berani untuk membicarakan mengenai kesehatan reproduksi. Hasil pengabdian ini sesuai dengan hasil pengabdian masyarakat yang dilakukan oleh Asda (2019) yang menyimpulkan adanya peningkatan pengetahuan kesehatan reproduksi pada siswi SMPN 2 Depok Sleman setelah target pengabdian mendengarkan ceramah mengenai kesehatan reproduksi.

Penyuluhan kesehatan reproduksi ini dilanjutkan dengan pemasangan poster di sekolah dan asrama supaya pengetahuan sasaran pengabdian masyarakat ini tetap terjaga retensinya sehingga tujuan pengabdian masyarakat untuk membentuk generasi sadar kesehatan reproduksi dapat tercapai. Pelaksanaan kegiatan pengabdian masyarakat ini memiliki keterbatasan, yaitu pelaksanaannya terpaksa dilakukan secara online. Hal ini karena pada saat pelaksanaan kegiatan di wilayah D.I.Y masih dalam masa tanggap darurat covid-19, yang tidak mengijinkan kegiatan di sekolah dilaksanakan secara tatap muka langsung, sehingga penyuluhan dan evaluasi terbatas pada domain kognitif. Domain keterampilan dan attitude sulit diajarkan dan diamati. Namun demikian, dengan pengetahuan yang cukup selanjutnya akan didapatkan perubahan perilaku pada siswi SMA Muhammadiyah 1 Bantul. Hal ini sesuai dengan teori yang dikemukakan oleh 
Notoatmojo (2012) yang menyebutkan bahwa pengetahuan atau kognitif merupakan domain yang penting dalam bentuk tindakan seseorang (overt behavior).

Simpulan

Kegiatan pengabdian masyarakat berupa webinar penyuluhan kesehatan reproduksi disertai pemasangan poster telah meningkatkan pengetahuan mengenai kesehatan reproduksi siswi SMA Muhammadiyah 1 Bantul secara signifikan.

\section{Ucapan Terima Kasih}

Terimakasih disampaikan kepada LP3M UMY selaku pemberi dana PPM dengan nomor kontrak 031/PEN-LP3M/I/2020 dan kepada seluruh panitia serta mitra yang telah berperan aktif dalam pelaksanaan PPM ini.

Daftar Pustaka

Asda, P. 2019 Informasi Kesehatan Reproduksi dan Penanganan Masalah Menstruasi Remaja Putri DIMAS, Vol. 1 No. 2, Juli 2019: 69-72 https://jurnal.stikeswirahusada.ac.id/dimas

Ernawati, H., 2018. Pengetahuan Kesehatan Reproduksi Remaja di Daerah Pedesaan. Indonesian Journal for Health Sciences. Vol. 02 No. 01. P. 58-64.

Johariyah, A., \& Mariati, T., (2018). Efektivitas penyuluhan kesehatan reproduksi remaja dengan pemberian modul terhadap perubahan pengetahuan remaja. Jurnal Manajemen Kesehatan Yayasan RS. dr. Soetomo, 4(1), 38-46. doi: 10.29241/jmk. v4i1.100

Kusmiran, E. (2012). Kesehatan reproduksi remaja dan wanita. Jakarta: Salemba Medika Miswanto, 2014. Pentingnya Pendidikan Kesehatan Reproduksi dan Seksualitas Remaja. Jurnal Studi Pemuda. Vol 3 no. 2. P. 111-121

Nasution, Sri Lilestina. 2012. Pengaruh Pengetahuan Tentang Kesehatan Reproduksi Remaja terhadap Perilaku Seksual Pranikah Remaja di Indonesia. Widyariset. Vol 15. No. 1 p.75-84

Notoadmojo, S. (2012). Promosi kesehatan dan perilaku kesehatan. Jakarta: Rineka Cipta

Yarza, H.N., Maesaroh, Kartikawati, E. 2019. Pengetahuan Kesehatan Reproduksi Remaja dalam Mencegah Penyimpangan Seksual. Sarwahita : Jurnal Pengabdian Kepada Masyarakat Vol. 16 No. 1 Tahun 2019|75 